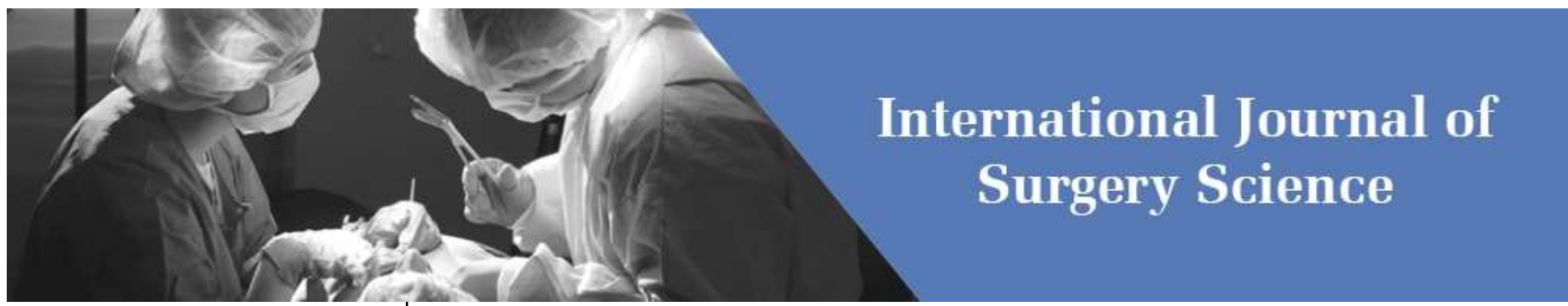

E-ISSN: 2616-3470

P-ISSN: 2616-3462

(C) Surgery Science

www.surgeryscience.com

2021; 5(1): 351-354

Received: 03-01-2021

Accepted: 15-02-2021

Dr. Elizabeth Anna Samue

Post Graduate Student,

Department of ENT, Sree

Mookambika Institute of Medical

Sciences, Kulasekharam, Tamil

Nadu, India

Dr. Chethan Kumar

Associate Professor, Department of

ENT, Sree Mookambika Institute

of Medical Sciences,

Kulasekharam, Tamil Nadu, India

Dr. KP Gopakumar

Professor and HOD, Department

of ENT, Sree Mookambika

Institute of Medical Sciences,

Kulasekharam, Tamil Nadu, India

Dr. Kiren T

Assistant Professor, Department of

ENT, Sree Mookambika Institute

of Medical Sciences,

Kulasekharam, Tamil Nadu, India

Dr. Anu Jacob

Senior Resident, Department of

ENT, Sree Mookambika Institute

of Medical Sciences,

Kulasekharam, Tamil Nadu, India

Corresponding Author:

Dr. Elizabeth Anna Samuel

Post Graduate Student,

Department of ENT, Sree

Mookambika Institute of Medical

Sciences, Kulasekharam, Tamil

Nadu, India

\section{A study on fat plug myringoplasty for small tympanic membrane perforation}

\author{
Dr. Elizabeth Anna Samuel, Dr. Chethan Kumar, Dr. KP Gopakumar, Dr. \\ Kiren T and Dr. Anu Jacob
}

DOI: https://doi.org/10.33545/surgery.2021.v5.i1f.636

\section{Abstract}

Introduction: Fat plug myringoplasty is an under-used technique to repair a small central tympanic membrane perforation. It is easy, quick and cost effective way with minimal morbidity. It can be done as an OPD procedure. The fat is readily available from ear lobe, abdomen and buttocks. Fat graft myringoplasty (FGM) is a noninvasive, but underused surgery for perforations of the tympanic membrane. It is also preferable for use in children. Fat tissue has been used as an autogenous material for different surgeries and is known to have a high capacity for resistance. Our study is conducted to evaluate the effectiveness of using fat plug in small central tympanic membrane perforation.

Aim: To evaluate the effectiveness of using fat plug in small central tympanic membrane perforation.

Materials and Methods: This study was conducted in the ENT department of Sree Mookambika Institute of Medical Sciences, Kulasekharam, Kanyakumari district in a time period from JUNE 2020 to November 2020.

The sample size was taken as 30 patients who had presented with complaints of ear discharge, and hearing loss, surgical procedure was done where a fat graft was inserted through the perforation for those patients who fulfilled the inclusion criteria. The study was conducted after obtaining the clearance from Institutional Human Ethical Committee.

Study Design: Prospective descriptive study.

Results and analysis: 30 patients were included in the study. Age range, 20 to 80 years with a tympanic perforation (size, up to one-quarter of the pars tensa). Out of which $24 \%$ had graft failure due to variety of causes. Success rate was $76 \%$ in our study, where as the study conducted by Ringenberg et al. The success rate was $86.5 \%$. Posterior perforations had an overall closure rate of $63 \%$, and in anterior perforations, the overall closure rate was $36 \%$.

Conclusion: In conclusion it is simple, safe, quick, economical procedure done under local anesthesia with as success rate as temporalis fascia and minimal or no morbidity and complications. The failure rate in our study was $24 \%$ due to infection, detached fat graft and dehiscence due to undersized grafts. Posterior perforations had an overall closure rate of $63 \%$, and in anterior perforations, the overall closure rate was $36 \%$. Pure tone audiometry was used to assess average AB gap pre- and post-operatively. Postoperatively there was an improvement in hearing compared to preoperative hearing.

Keywords: Fat plug myringoplasty, tympanic membrane, minimal morbidity

\section{Introduction}

Myringoplasty is a well-known operation to all ENT surgeons. The first recorded attempt at myringoplasty was by Marcus Banzer in 1640. The first surgical closure using autograft (a full thickness free skin graft) was performed by Berthold in 1878 and he introduced the word 'Myringoplasty'. Wulstein and Zoellner popularised myringoplasty technique in 1951 and with improved optics and microsurgery it is still practiced in modern days. Various graft material has been used since this time are skin, amniotic membrane, mucous membrane, dura mater, cornea, periosteum, perichondrium, vein, adipose tissue and temporalis fascia. of these, temporalis fascia has become the most popular grafting material.

In $1962^{[3]}$, Ringenberg successfully used adipose tissue - fat to repair a small tympanic membrane perforation. Mitchell et al., $1997^{[12]}$ used fat in 342 children to close small tympanic membrane perforation achieving $92 \%$ success rate.

Fat plug myringoplasty is an under-used technique to repair a small central tympanic membrane perforation. It is easy, quick and cost effective way with minimal morbidity. 
It can be done as an OPD procedure. The fat is readily available from ear lobe, abdomen and buttocks. Fat graft myringoplasty (FGM) is a noninvasive, but underused surgery for perforations of the tympanic membrane. It is also preferable for use in children. Fat tissue has been used as an autogenous material for different surgeries and is known to have a high capacity for resistance.

Other authors confirmed the technique and it has been used with good closure results to the present day. However, FGM is still an underused procedure among otosurgeons, especially for large perforations, despite its success in repairing TM perforations.

\section{Aim of the study}

To evaluate the effectiveness of using fat plug in small central tympanic membrane perforation.

\section{Materials and Methods}

Study Place: Sree Mookambika Institute of Medical Sciences, Kulasekharam, Kanyakumari district

\section{Study Design: Prospective Descriptive Study}

Study Period: June 2020 to November 2020

\section{Inclusion criteria}

All the patients were included in the study after careful selection as follows.

1. A small central perforation the size being no more than 25 $\%$ of tympanic membrane by visual assessment.

2. At least 6 months old perforation and dry for 6-8 weeks preoperatively.

3. No hyperplastic mucosa of the middle ear and no discharge from the ear.

4. Airbone gap less than $30 \mathrm{db}$

\section{Exclusion criteria}

1. A small central perforation of size more than $25 \%$ of tympanic membrane by visual assessment

2. Patients with major Eustachian tube dysfunction problems.

3. Airbone gap more than $30 \mathrm{db}$

\section{Procedure}

Each patient underwent a careful preoperative otomicroscopic examination. The subjects were then assigned (according to the site of the perforation) to 1 of 4 groups: anterosuperior, anteroinferior, posterosuperior, or posteroinferior.

The surgical procedure in each patient was performed. Atropine sulfate $0.5 \mathrm{mg}$ and promethazine chlorhydrate $50 \mathrm{mg}$ were administrated intramuscularly 30 minutes before surgery. The patient was then placed in the standard otosurgical position and was draped via sterile technique. The osteocartilaginous junction of the external ear canal was infiltrated with $2 \mathrm{~mL}$ of $2 \%$ lidocaine with 1:100 000 epinephrine. The edges of the perforation were excised with a sickle knife and a Rosen needle and were removed with a microforceps. After that surgical phase, the dimensions of the perforation were reevaluated. The skin of the posterior surface of the ear lobule was infiltrated with $0.5 \mathrm{~mL}$ of the same solution without inducing swelling inside the fat tissue. A $5 \mathrm{~mm}$ incision was performed, and a skinless fat graft that was 2 to 3 times larger than the perforation and that had been shaped like an hourglass for better stabilization was selected. The fat graft was inserted through the perforation and was covered with a small piece of absorbable gelatin sponge (Gelfoam). Neither packing nor dressing was used. After surgery, the patient was instructed to instill 3 drops of neomycin into the ear canal daily for 1 week and to take oral antibiotics, the selection of which was based on each patient's sensitivity to specific allergens, for 6 days. All patients were discharged within 1 hour after surgery. The duration of surgery (the interval from the disinfection of the patient to the instillation of the postsurgically applied ear drops) was noted, and all patients were reexamined 1 week, 1 to 6 months, and 1 year after surgery.

\section{Results and Analysis \\ Demographic details}

Thirty patients were included in the study. Age range, 20 to 80 years with a tympanic perforation (size, up to one-quarter of the pars tensa) that resulted from any of a variety of causes (trauma, otitis media, prior tympanic surgery, grommet removal).

\section{Pathology}

Perforations of the tympanic membranes are caused by infections or trauma. Regeneration of intact tympanic membrane following either of the causes is common. The actual cause of the persistent perforation is not clearly understood. Duhlap and Schuknecht have noted that in permanent perforations, the outer squamous epithelium grows medially around the edge of the perforation to contact the inner mucosal layer. This acts as a limiting healing barrier on the middle connective tissue layer preventing closure in a small percentage of perforated ears.

Table 1: Graft Failure

\begin{tabular}{|c|c|c|c|c|}
\hline \multicolumn{5}{|c|}{ distribution of graft failure } \\
\hline Age in years & \multicolumn{2}{|c|}{ No of patients } & \multicolumn{2}{|c|}{ Graft failure } \\
\hline $20-40$ & 10 & & 2 & \\
\hline $41-60$ & 10 & & 2 & \\
\hline $61-80$ & 10 & & 3 & \\
\hline
\end{tabular}

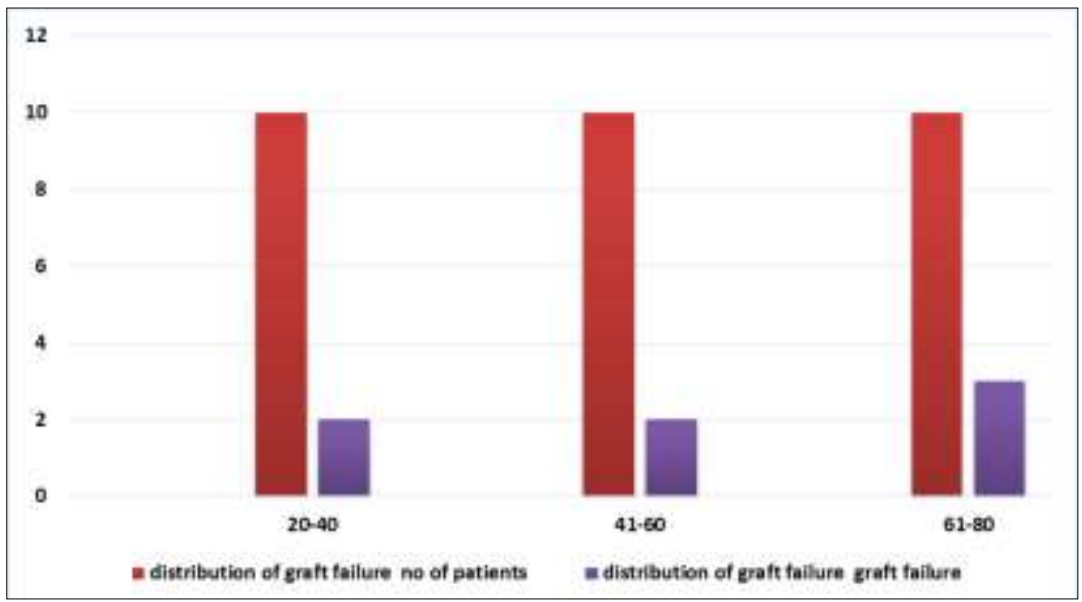

Fig 1: Shows distribution graft failure no of patients and graft failure 
Table 2: Site of Closure

\begin{tabular}{|c|c|c|}
\hline Perforation site & closure & percentage \\
\hline anterosuperior & 6 & 20 \\
\hline anteroinferior & 5 & 16 \\
\hline posterosuperior & 10 & 33 \\
\hline posteroinferior & 9 & 30 \\
\hline
\end{tabular}

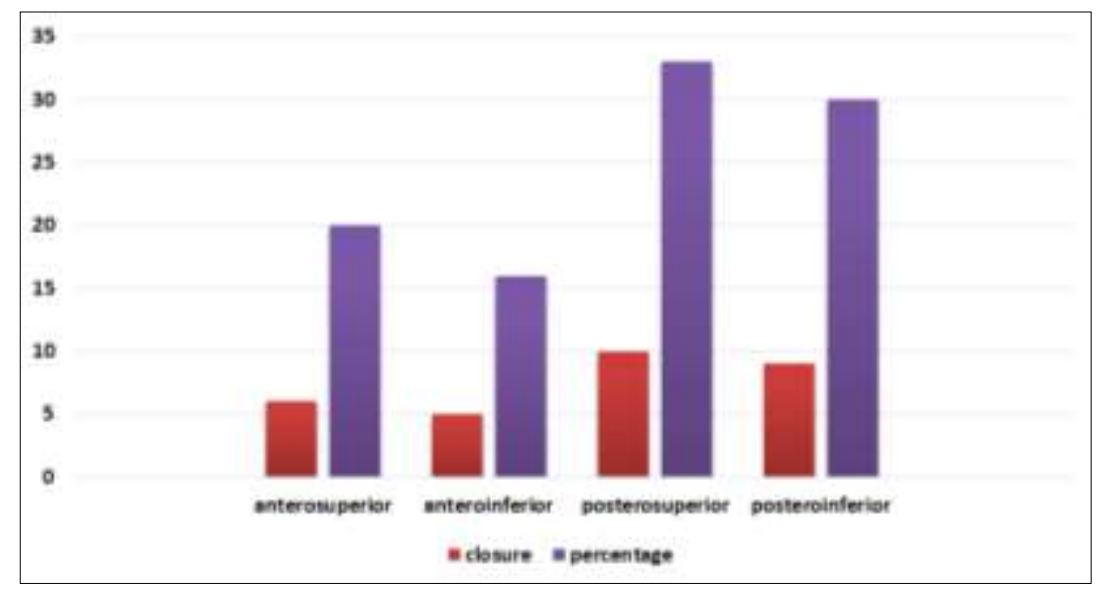

Fig 2: Shows closure and percentage

Table 3: PRE and Postop AB Gap on Pure Tone Audiogram

\begin{tabular}{|c|c|c|}
\hline hearing loss in dB & Preop (\%) & Postop (\%) \\
\hline$<=10 \mathrm{~dB}$ & $5(16)$ & $3(10)$ \\
\hline 11 to $20 \mathrm{~dB}$ & $5(16)$ & $4(13)$ \\
\hline 21 to $20 \mathrm{~dB}$ & $10(33)$ & $6(20)$ \\
\hline$>30 \mathrm{~dB}$ & $10(33)$ & $8(26)$ \\
\hline
\end{tabular}

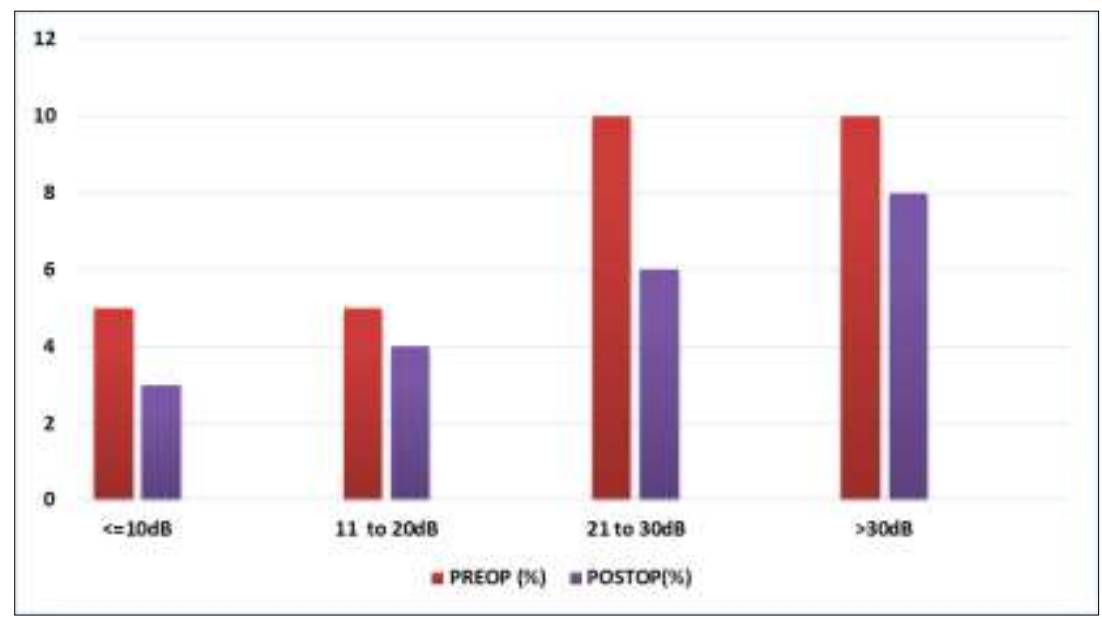

Fig 3: Shows preop(\%) and postop(\%)

\section{Discussion}

Ringenberg first described FM, with a success rate of $87 \%$ for small perforations. Since then, studies have shown success rates ranging from $76 \%$ to $92 \%$ in cases of small perforations. Deddens et al. had reported that size of TM perforation was a crucial factor. Perforations, in their series, were 5-30\% of the drum surface, which was a good prognostic factor for an FM as compared to larger perforations for fat graft alone as was also observed by us. The fat graft can be harvested from the abdomen, buttock and ear lobule. The ear lobule fat harvesting is much simpler as it is done from the same sterile area of the surgical field prepared for the fat tympanoplasy and its scar is almost invisible. The fat of ear lobule is denser with big revascularization activity and acts as a good template for mucosal and epithelial growth. There is significant bulging postoperatively on the TM till the end of the 3rd month and after that it progressively disappears and gets converted into a smooth sclerotic area on the TM at the 5th month. This phenomenon was also observed by us in patients where graft uptake was there. There are two histological theories of fat grafts "The host cell replacement theory" of Neuhof and "The cell survival theory" of Peer. The host cell replacement theory states that all the original cells die and are totally replaced by new wondering adipocytes or by fibroblasts. The cell survival theory states that not all the original adipose cells die. Those fat cells which receive adequate blood supply survive whereas remaining degenerate, thus explaining loss of volume. The transplanted fat cells are not replaced by scar tissue, instead a connective tissue capsule outside the fat graft begins 3 weeks after transplantation, which becomes progressively thinner over the course of a year. 
Fat tissue provides the basic requirement for the grafting of the $\mathrm{TM}$ with its own favorable characteristics.

\begin{tabular}{|c|c|c|}
\hline Authors & No. of Patients & Closure (\%) \\
\hline Ringenberg & 65 & 86.5 \\
\hline Terry and colleagues & 50 & 76 \\
\hline Gross and colleagues & 62 & 79.2 \\
\hline Deddens and colleagues & 28 & 89 \\
\hline Kaddour & 11 & 80 \\
\hline Mitchell and colleagues & 342 & 92 \\
\hline Liew and colleagues & 13 & 100 \\
\hline Ayache and colleagues & 45 & 91.1 \\
\hline Hagemann and Hausler & 44 & 91 \\
\hline Ozgursoy and Yorulmaz & 30 & 82.4 \\
\hline Landsberg and colleagues & 38 & 81.6 \\
\hline Our study & 30 & 76 \\
\hline
\end{tabular}

The failure rate in our study was $7 \%$ due to infection, detached fat graft and dehiscence due to undersized grafts. Fiorino and Barbieri described various causes of failure. Immediate failures due to technical difficulties such as anterior perforations, inadequate graft support, poor vascular supply or infection and delayed failures due to atrophic TM, infections or Eustachian tube dysfunction with change in the TM structure. Hegazy et al. described technical operative points during fat grafting that is, graft size in relation with the perforation, degree of lateral bulge in the fat plug and moistening of the lateral side of the graft are important factors for success in the fat grafting procedure.

\section{Summary}

Thirty patients were included in the study. Age range, 20 to 80 years with a tympanic perforation (size, up to one-quarter of the pars tensa) that resulted from any of a variety of causes (trauma, otitis media, prior tympanic surgery, grommet removal). Patients coming to ENT opd are screened by questionnaire and direct history taking. Each patient underwent a careful preoperative otomicroscopic examination. The surgical procedure in each patient was performed. After surgery, the patient was instructed to instill 3 drops of neomycin into the ear canal daily for 1 week and to take oral antibiotics. All patients were discharged within 1 hour after surgery. The duration of was noted, and all patients were reexamined 1 week, 1 to 6 months, and 1 year after surgery.

\section{Conclusion}

In conclusion it is simple, safe, quick, economical procedure done under local anesthesia with as success rate as temporalis fascia and minimal or no morbidity and complications. The failure rate in our study was $24 \%$ due to infection, detached fat graft and dehiscence due to undersized grafts. Posterior perforations had an overall closure rate of $63 \%$, and in anterior perforations, the overall closure rate was $36 \%$. Pure tone audiometry was used to assess average $\mathrm{AB}$ gap pre-and post-operatively. Postoperatively there was an improvement in hearing compared to preoperative hearing.

\section{References}

1. Gibb AG, Chang SK. Myringoplasty (A review of 365 operations). J Laryngol Otol 1982;96:91530.

2. Downey TJ, Champeaux AL, Silva AB. Allo Derm tympanoplasty of tympanic membrane perforations. Am J Otolaryngol 2003;24:6-13.

3. Ringenberg JC. Fat graft tympanoplasty. Laryngoscope 1962;72:188-92.

4. Imamoglu M, Isik AU, Acuner O, Harova G, Bahadir O.
Fat-plug and paper-patch myringoplasty in rats. J Otolaryngol 1998;27:31821.

5. Gold SR, Chaffoo RA. Fat myringoplasty in the guinea pig. Laryngoscope 1991;101:1-5.

6. Ayache S, Braccini F, Facon F, Thomassin JM. Adipose graft: An original option in myringoplasty. Otol Neurotol 2003;24:158-64.

7. De S, Karkanevatos A, Srinivasan VR, Roland NJ, Lesser TH. Myringoplasty using A subcutaneous soft tissue graft. Clin Otolaryngol Allied Sci 2004;29:314-7.

8. Kaddour HS. Myringoplasty under local anaesthesia: day case surgery. Clin Otolaryngol Allied Sci 1992;17:567-8.

9. Terry RM, Bellini MJ, Clayton MI, Gandhi AG. Fat graft myringoplasty-a prospective trial. Clin Otolaryngol Allied Sci 1988;13:227-9.

10. Deddens AE, Muntz HR, Lusk RP. Adipose myringoplasty in children. Laryngoscope 1993;103:216-9.

11. Gross CW, Bassila M, Lazar RH, Long TE, Stagner S. Adipose plug myringoplasty: an alternative to formal myringoplasty techniques in children. Otolaryngol Head Neck Surg 1989;101:617-20.

12. Mitchell RB, Pereira KD, Lazar RH. Fat graft myringoplasty in children A safe and successful day-stay procedure. J Laryngol Otol 1997;111:106-8.

13. Liew L, Daudia A, Narula AA. Synchronous fat plug myringoplasty and tympanostomy tube removal in the management of refractory otorrhoea in younger patients. Int J Pediatr Otorhinolaryngol 2002;66:291-6.

14. Hagemann M, Hausler R. Tympanoplasty with adipose tissue. Laryngorhinootologie 2003;82:3936.

15. Landsberg R, Fishman G, DeRowe A, Berco E, Berger G. Fat graft myringoplasty: results of a long-term follow-up. J Otolaryngol 2006;35:44-7. 